\title{
Flavin mononucleotide (FMN)-based fluorescent protein (FbFP) as reporter for promoter screening in Clostridium cellulolyticum
}

\author{
Lin Teng ${ }^{\mathrm{a}, \mathrm{b}}$, Kun Wang ${ }^{\mathrm{c}}$, Jian $\mathrm{Xu}^{\mathrm{a}, *}$, Chenggang $\mathrm{Xu}^{\mathrm{a}, *}$

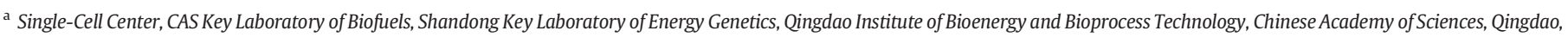 \\ Shandong 266101, China \\ b University of Chinese Academy of Sciences, Beijing 100049, China

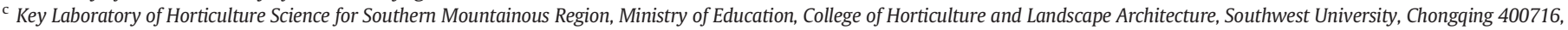 \\ China
}

\section{A R T I C L E I N F O}

\section{Article history:}

Received 9 July 2015

Received in revised form 28 September 2015

Accepted 28 September 2015

Available online 30 September 2015

\section{Keywords:}

Clostridium cellulolyticum

FbFP

Promoter screening

Constitutive

Inducible

\begin{abstract}
A B S T R A C T
Conventional methods for screening promoters in anaerobic bacteria are generally based on detection of enzymatic reactions and thus usually complicated or strain specific. Therefore a more efficient and universal method will be valuable. Here, using cellulolytic bacteria Clostridium cellulolyticum H10 as a model, we employed an oxygen-independent flavin-based fluorescent protein (FbFP) derived from Pseudomonas putida as a quantitative reporter for the screening of promoter via monitoring fluorescence intensity. The stability and reliability of FbFP fluorescence were proven by the high correlation $\left(R^{2}=0.87\right)$ between fluorescence intensity and abundance of FbFP. Moreover, two endogenous promoters with exceptional performance were identified and characterized, including a constitutive promoter p3398 and an inducible promoter p1133. Compared to the existing reporter systems widely used in clostridia, this FbFP-based method is more rapid, intuitive and versatile, and the endogenous promoters reported here should enrich the synthetic biology toolbox for this and related organisms.
\end{abstract}

(c) 2015 Elsevier B.V. All rights reserved.

\section{Introduction}

Clostridium cellulolyticum $\mathrm{H} 10$ is a typical mesophilic, anaerobic and cellulolytic bacterium (Petitdemange et al., 1984), and has been one model strain for studying bacterial degradation of cellulose (Hemme et al., 2010; Xu et al., 2013; 2015). This bacterium produces extracellular enzymes assembled in high-molecular-mass complexes named cellulosome, which hydrolyze plant cell wall polysaccharides into simple sugars (Blouzard et al., 2010; Fendri et al., 2013; Madarro et al., 1991). In addition to cellulose, it grows on a wide variety of carbohydrates, including soluble cellodextrins, glucose, xylan, xylose, arabinose, fructose, galactose, mannose and ribose (Mohand-Oussaid et al., 1999; Petitdemange et al., 1984; Saxena et al., 1995). With the completion of genome sequencing (Hemme et al., 2010) and transcriptome analysis under various carbon sources (Xu et al., 2013), C. cellulolyticum H10

\footnotetext{
Abbreviations: FbFP, flavin mononucleotide (FMN)-based fluorescent protein; ERBRs, enzymatic reaction based reporters; P3398, cells harboring plasmid pXL008; P1133, cells harboring plasmid pXL007.

* Corresponding authors at: Single-Cell Center, CAS Key Laboratory of Biofuels and Shandong Key Laboratory of Energy Genetics, Qingdao Institute of Bioenergy and Bioprocess Technology, Chinese Academy of Sciences, Qingdao, Shandong, China.

E-mail addresses: xujian@qibebt.ac.cn (J. Xu), xucg@qibebt.ac.cn (C. Xu).
}

has also been widely employed for dissecting regulatory machinery in cellulose hydrolysis (Desvaux, 2005), as well as for exploring biotechnological applications in industry (e.g. Consolidated Bioprocessing, which combines cellulase production and ethanol production in a single bioreactor) (Higashide et al., 2011; Lin et al., 2011; Lynd et al., 2005).

Genetic engineering of $C$. cellulolyticum H10 is crucial for its potential as chassis for synthetic biology. Genetic tools such as DNA transfer (Tardif et al., 2001), heterologous expression (Guedon et al., 2002), mobile Group-II intron targeted gene inactivation system (Cui et al., 2012; 2014; Li et al., 2012) and Cas9-based genome editing technology (Xu et al., 2014) usually demand access to a repertoire of both constitutive and inducible promoter systems. However, despite the very limited number of promoters derived from Clostridium acetobutylicum ATCC 824 (Cui et al., 2012; Mingardon et al., 2011; Shao et al., 2007), there has been a paucity of endogenous promoters that require no introduction of additional regulators in C. cellulolyticum H10 (Pyne et al., 2014). Therefore, it is urgent to develop efficient endogenous promoters in C. cellulolyticum.

As measurement of promoter activities relies on efficient and quantitative reporter expression, the development of reporters plays a key role in screening of promoters. To date, numerous reporters have been discovered, including alkaline phosphatase (AP) (Shiraiwa et al., 2007), chloramphenicol acetyltransferase (CAT) (Schwarz et al., 2004), luciferases (lux reporter system) (Feustel et al., 2004; Phillips-Jones, 
2000), $\beta$-galactosidase ( $\beta$-gal) (Feustel et al., 2004), fluorescent proteins (Yarbrough et al., 2001; Zhao et al., 2005), and $\beta$-lactamase (Campbell, 2004). These reporters can be divided into two classes: one is enzymatic reaction based reporters (ERBRs), and the other is based on spontaneous fluorophore (i.e., Green Fluorescent Protein (GFP)). For ERBRs, there are limitations as follows: $i$ ) complicated process, for the widely used GusA assay, at least three steps were involved, including cell lysis by sonication, enzymatic reaction of substrates and fluorescence intensity measurement (Zhang et al., 2015); and ii) strain selective, certain kinds of ERBRs usually have high endogenous enzyme activities, such as AP and $\beta$-galactosidase (Jiang et al., 2008). GFP, characterized by its direct visibility, is widely used from bacterial to mammalian cells (Davis and Vierstra, 1998; Dooley et al., 2004; Ducrest et al., 2002; Leveau and Lindow, 2001). This kind of reporters relies on spontaneous fluorophore without cofactors added, facilitating high throughput when combined with flow cytometry (e.g., fluorescence-activated cell sorting, FACS) (Ducrest et al., 2002). However, formation of the chromophores strictly relies on oxygen (Drepper et al., 2007; Jiang et al., 2008), which hinders its application in anaerobic biological systems. Targeting this challenge, Drepper et al. (2007) constructed FMNbased fluorescent proteins (FbFPs) to allow in vivo labeling without oxygen, which provides a fluorescent reporter system in anaerobic bacteria (Lobo et al., 2011).

Here we report a simple and robust system for screening of promoters (constitutive or inducible) based on fluorescence intensity of FbFP in $C$. cellulolyticum H10. Moreover, based on transcriptomic data in our previous study (Xu et al., 2013), several promoters with different transcriptional activities were cloned and fluorescence intensities of FbFP were compared. The correlation efficient between fluorescence intensity and abundance of FbFP protein was high $\left(R^{2}=0.87\right)$. Compared to the enzymatic-reaction-based methods for promoter screening in anaerobic bacteria, this approach is much easier, more rapid and can potentially be extended to other bacterial species including thermophilic bacteria. Furthermore, two native and valuable promoters, including a highly efficient constitutive one and a D-xylan-inducible one, exhibit outstanding performance in the FbFP-fluorescence based screening. The methods and tools introduced in this study should enable new applications that explore genetically engineered $C$. cellulolyticum and related clostridia.

Table 1

Bacterial strains and plasmids used in this study.

\begin{tabular}{|c|c|c|}
\hline $\begin{array}{l}\text { Strains and } \\
\text { plasmids }\end{array}$ & Relevant characteristic(s) & Source or reference \\
\hline \multicolumn{3}{|l|}{ Strain } \\
\hline $\begin{array}{l}\text { Escherichia coli } \\
\qquad \mathrm{DH} 5 \alpha\end{array}$ & $\begin{array}{l}\mathrm{F}^{-} \varphi 80 \text { lacZ } \Delta \mathrm{M} 15 \Delta(\text { lacZYA-argF }) \mathrm{U} 169 \\
\text { endA1 recA1 hsdR17 }\left(\mathrm{r}_{\mathrm{k}}^{-}, \mathrm{m}_{\mathrm{k}}^{+}\right) \\
\text {supE44入-thi-1 gyrA96 relA1 phoA }\end{array}$ & Transgene \\
\hline $\begin{array}{l}\text { Clostridium } \\
\text { cellulolyticum } \\
\text { H10 }\end{array}$ & Wild type strain & $\begin{array}{l}\text { Granted from Zhou } \\
\text { Jizhong (Hemme et al., } \\
\text { 2010) }\end{array}$ \\
\hline \multicolumn{3}{|l|}{ Plasmids } \\
\hline pMTC6 & $\begin{array}{l}\mathrm{Mls}^{\mathrm{R}}, \mathrm{Amp}^{\mathrm{R}}, \text { E. coli-C. cellulolyticum } \\
\text { shuttle vector, containing fbfp, thl } \\
\text { promoter, thl terminator from } \\
\text { C. acetobutylicum }\end{array}$ & $\begin{array}{l}\text { Granted from Cui Qiu } \\
\text { (Cui et al., 2012) }\end{array}$ \\
\hline pXL005 & $\begin{array}{l}\text { Derived from pMTC6, containing } \\
\text { promoter of Ccel_0750 instead of pthl }\end{array}$ & This study \\
\hline pXL006 & $\begin{array}{l}\text { Derived from pMTC6, containing } \\
\text { promoter of Ccel_0902 instead of pthl }\end{array}$ & This study \\
\hline pXL007 & $\begin{array}{l}\text { Derived from pMTC6, containing } \\
\text { promoter of Ccel_1133 instead of pthl }\end{array}$ & This study \\
\hline pXL008 & $\begin{array}{l}\text { Derived from pMTC6, containing } \\
\text { promoter of Ccel_3398 instead of pthl }\end{array}$ & This study \\
\hline pXL009 & $\begin{array}{l}\text { Derived from pMTC6, containing } \\
\text { promoter of Ccel_1979 instead of pthl }\end{array}$ & This study \\
\hline pXL010 & $\begin{array}{l}\text { Derived from pMTC6, containing } \\
\text { promoter of Ccel_1987 instead of pthl }\end{array}$ & This study \\
\hline
\end{tabular}

\section{Materials and methods}

\subsection{Strains, plasmids and growth conditions}

The bacterial strains and plasmids used in this study are listed in Table 1. Escherichia coli DH5 $\alpha$ was used as the host strain for routine cloning and incubated at $37{ }^{\circ} \mathrm{C}$ in Luria-Bertani (LB) medium. C. cellulolyticum ATCC 35319 (H10) was routinely cultured anaerobically in Hungate tubes at $33-35{ }^{\circ} \mathrm{C}$ in DCB-1 medium (Loffler et al., 1996) supplemented with $3.0 \mathrm{~g} / \mathrm{L}$ of D-cellobiose as the sole carbon source (default carbon source unless otherwise stated). The medium for cultivation was depleted of oxygen in Anaerobic Chamber (COY, USA) using resazurin $(0.0005 \% \mathrm{~g} / \mathrm{L})$ as the indicator and then sterilized at $121{ }^{\circ} \mathrm{C}$ for $20 \mathrm{~min}$. Bacterial culture was inoculated using injection syringe. A shuttle vector, pMTC6, which contains a fluorescence protein gene $(f b f p)$ from Pseudomonas putida, was used for detection and quantification of promoter activity in C. cellulolyticum (Cui et al., 2012). Competent cells of $C$. cellulolyticum were prepared by washing cells with electroporation buffer ( $\mathrm{pH}=7.4 ; 5 \mathrm{mM}$ PBS buffer, $1 \mathrm{mM} \mathrm{MgCl}_{2}$, $0.27 \mathrm{M}$ sucrose) at the late-exponential phase, followed by electrotransformation in $0.1 \mathrm{~cm}$ electroporation cuvette using $100 \mu \mathrm{L}$ competent cells (BTX ECM630; 750v, pulse duration 6 ms) (Guedon et al., 2002). Transformants were screened on agar plates based on their resistance to erythromycin. Plates were placed in AnaeroJar (BD GasPak, USA) with AnaeroPack-Anaero (MGC, Japan) added for oxygen removal at a $35{ }^{\circ} \mathrm{C}$ incubator. When required, the media for $E$. coli and $C$. cellulolyticum were supplemented with $100 \mu \mathrm{g} / \mathrm{mL}$ ampicillin or $20 \mu \mathrm{g} /$ mL erythromycin, respectively.

\subsection{DNA manipulation}

Isolation and manipulation of recombinant DNA were performed using standard techniques. DNA was amplified by PCR using synthetic oligonucleotide primers and Expand High-Fidelity polymerase (Roche, China) (the PCR primers are listed in Table 2). PCR products of various promoter regions were purified with a Nucleospin extract purification kit (OMEGA, Beijing, China) and digested with restriction enzyme PstI and MluI. Then the digested fragments were respectively ligated to the

Table 2

Primers used in this study.

\begin{tabular}{|c|c|c|}
\hline $\begin{array}{l}\text { Primer } \\
\text { name }\end{array}$ & 5'-to-3' sequence & Description \\
\hline Pr_0750F & $\begin{array}{l}\text { AACTGCAGCTTATATTAACC } \\
\text { ATGGGAT }\end{array}$ & \multirow[t]{2}{*}{$\begin{array}{l}\text { To amplify the promoter of Ccel_0750 } \\
\text { and generate plasmid pXL005 }\end{array}$} \\
\hline Pr_0750R & $\begin{array}{l}\text { CGACGCGTCATTTATTTTCC } \\
\text { TCCTTTC }\end{array}$ & \\
\hline Pr_0902F & $\begin{array}{l}\text { AACTGCAGAGTACTAGCTCC } \\
\text { CTTCAAAT }\end{array}$ & \multirow[t]{2}{*}{$\begin{array}{l}\text { To amplify the promoter of Ccel_0902 } \\
\text { and generate plasmid pXL006 }\end{array}$} \\
\hline Pr_0902R & $\begin{array}{l}\text { CGACGCGTCATACTAAAAAA } \\
\text { TCCTCCC }\end{array}$ & \\
\hline Pr_1133F & $\begin{array}{l}\text { AAACTGCAGTTTAGAGCTAG } \\
\text { TTCGTTTACAGAC }\end{array}$ & \multirow[t]{2}{*}{$\begin{array}{l}\text { To amplify the promoter of Ccel_1133 } \\
\text { and generate plasmid pXL007 }\end{array}$} \\
\hline Pr_1133R & $\begin{array}{l}\text { CCGACGCGTCATATTTTTGC } \\
\text { CTCCTTTATAATTATG }\end{array}$ & \\
\hline Pr_3398F & $\begin{array}{l}\text { AACTGCAGTCAAGATATTTT } \\
\text { ATAACTAAAGAT }\end{array}$ & \multirow[t]{2}{*}{$\begin{array}{l}\text { To amplify the promoter of Ccel_3398 } \\
\text { and generate plasmid pXL008 }\end{array}$} \\
\hline Pr_3398R & $\begin{array}{l}\text { CGACGCGTCATGTTCTCAAA } \\
\text { TCCTCC }\end{array}$ & \\
\hline Pr_1979F & $\begin{array}{l}\text { AACTGCAGAAAGCATTTTCC } \\
\text { TTTCC }\end{array}$ & \multirow[t]{2}{*}{$\begin{array}{l}\text { To amplify the promoter of Ccel_1979 } \\
\text { and generate plasmid pXL009 }\end{array}$} \\
\hline Pr_1979R & $\begin{array}{l}\text { CGACGCGTCATAGTAATCAC } \\
\text { CTCCTGC }\end{array}$ & \\
\hline Pr_1987F & $\begin{array}{l}\text { AACTGCAGAGAGGTTAATCA } \\
\text { CAAAACG }\end{array}$ & \multirow[t]{2}{*}{$\begin{array}{l}\text { To amplify the promoter of Ccel_1987 } \\
\text { and generate plasmid pXL010 }\end{array}$} \\
\hline Pr_1987R & $\begin{array}{l}\text { CGACGCGTCATGTCTTAATC } \\
\text { CCTCC }\end{array}$ & \\
\hline
\end{tabular}


shuttle vector pMTC6 which was digested with the same enzymes, resulting in the replacement of the original pthl promoter (promoter for FbFP on pMTC6) by various PCR fragments (as described above). Using wild type $C$. cellulolyticum $\mathrm{H} 10$ as the host, all of the pMTC6 derivatives (pXL005, pXL006, pXL007, pXL008, pXL009, pXL010) were MspI methylated and then electro-transformed anaerobically as described in previous studies (Tardif et al., 2001; Guedon et al., 2002). All the transformants were isolated on selective solid medium (DCB-1) containing $20 \mu \mathrm{g} / \mathrm{mL}$ erythromycin.

\subsection{Growth measurements}

Two methods were involved in growth measurements. One is the traditional method of optical density measurement at $600 \mathrm{~nm}\left(\mathrm{~A}_{600}\right)$, and the other is cellular protein concentration determination. For the latter method, cells were lysed in $\mathrm{NaOH} / \mathrm{SDS}$ solution (according to alkaline lysis procedure), and the protein concentration in the supernatant was estimated using BCA Protein Assay Kit (Sangon, China) with BSA as standards after cell debris were pelleted and removed (especially when cells were cultivated in insoluble carbon sources). Growth measurements for the two methods were each performed in three biological replicates.

\subsection{Identification of FbFP protein by LC-MS}

One hundred and fifty microgram of each cytoplasmic extract of ultrasonically broken cells was diluted in PBS ( $\mathrm{pH}=7.4$ ) buffer and denatured in loading buffer before separating on a 15\% acrylamide SDS-PAGE gel (Laemmli, 1970). Proteins were visualized by Coomassie Brilliant Blue staining (Wong et al., 2000). Then the procedure was as follows: i) Decoloration. The band of target protein was firstly cut into $1 \mathrm{~mm}^{3}$ size each, placed in an EP tube, and washed with $400 \mu \mathrm{L} 100 \mathrm{mM}$ $\mathrm{NH}_{4} \mathrm{HCO}_{3} / 30 \% \mathrm{ACN}$ until the gel was totally decolorized. Then the supernatant was discarded and the gel freeze-dried; $i i)$ Washing. Proteins were reduced and alkylated by successive incubation in $100 \mathrm{mM}$ $\mathrm{NH}_{4} \mathrm{HCO}_{3}$ and $100 \mathrm{mM}$ DTT for $30 \mathrm{~min}$ at $56{ }^{\circ} \mathrm{C}$, and in $100 \mathrm{mM}$ $\mathrm{NH}_{4} \mathrm{HCO}_{3}$ and $200 \mathrm{mM}$ iodoacetamide (IAA) for $20 \mathrm{~min}$ in a darkness at room temperature. An additional cycle of washing in $\mathrm{NH}_{4} \mathrm{HCO}_{3}$ and $\mathrm{NH}_{4} \mathrm{HCO}_{3} / \mathrm{ACN}$ was performed and then the proteins were freezedried; and iii) Digestion. Proteins were digested by incubating the gel slices in $50 \mu \mathrm{L}$ modified porcine trypsin solution $(10 \mathrm{ng} / \mu \mathrm{L}$ in $50 \mathrm{mM}$ $\mathrm{NH}_{4} \mathrm{HCO}_{3}$; Promega, China) at $4{ }^{\circ} \mathrm{C}$ for 30-60 min. Trypsin digestion was performed overnight at $37^{\circ} \mathrm{C}$ for about $20 \mathrm{~h}$. The peptide mixture was centrifuged at $4{ }^{\circ} \mathrm{C}, 12,000 \mathrm{rpm}, 20 \mathrm{~min}$, and then the supernatant was transferred into an intubation tube (about 20-40 $\mu \mathrm{L}$ ) and stored at $-80{ }^{\circ} \mathrm{C}$ for further qualitative analysis by LC-MS (Thermo Fisher LTQ XL, USA).

\subsection{Relative quantification of FbFP protein}

The SDS-PAGE gel was relatively quantified by Gel Imaging System (Bio-Rad GelDoc XR) with a spectrum (representing total protein) generated for each gel lane. Then each spectrum was subtracted by that of a blank lane and baseline corrected in the software LabSpec 5 (Horiba Scientific, France). Percentage of the targeted protein was calculated by dividing peak area of targeted protein by total area of the spectrum.

\subsection{Screening of promoter activity based on fluorescence intensity}

Each of the FbFP promoter harboring strains was 1:100 inoculated into certain substrates ( $3 \mathrm{~g} / \mathrm{L}$ sugars, including D-cellobiose, D-xylose, L-arabinose, D-glucose and D-xylan) for pre-adaptation before fluorescence intensity measurement (Xu et al., 2013). Cell pellets (late-exponential phase) cultivated in triplicate on each carbon source were washed once with $0.01 \mathrm{M}$ PBS buffer $(\mathrm{pH}=7.4, \mathrm{NaCl} 137 \mathrm{mmol} / \mathrm{L}, \mathrm{KCl}$
$2.7 \mathrm{mmol} / \mathrm{L}, \mathrm{Na}_{2} \mathrm{HPO}_{4} 10 \mathrm{mmol} / \mathrm{L}, \mathrm{KH}_{2} \mathrm{PO}_{4} 2 \mathrm{mmol} / \mathrm{L}$ ), then resuspended in $1.5 \mathrm{~mL}$ PBS for fluorescence intensity measurement. The excitation and emission wavelengths of FbFP were firstly verified and determined at $452 \mathrm{~nm}$ and $495 \mathrm{~nm}$ (Fig. S2), respectively, with other parameters set as integration time $5 \mathrm{~s}$, delay time $0.1 \mathrm{~s}$ and PMT Voltage $950 \mathrm{~V}$ (Drepper et al., 2007). This verification was carried out for three times. Finally, fluorescence intensity at $495 \mathrm{~nm}$ was normalized by the corresponding $A_{600}$ or total protein concentration for each sample with that of wild type cells as the baseline.

\subsection{Analysis of inducible promoter}

C. cellulolyticum strain P1133 (with plasmid pXL007) was recovered and cultivated at $33-35{ }^{\circ} \mathrm{C}$ till the late-exponential phase with $3 \mathrm{~g} / \mathrm{L} \mathrm{D-}$ cellobiose as the sole carbon source. Then the culture was inoculated at 1:100 ratio into dozens of $10 \mathrm{~mL}$ Hungate tubes (D-cellobiose as the carbon source). The inoculum were cultured for about twenty hours until the early-exponential phase $\left(\sim \mathrm{A}_{600}=0.2\right)$, followed by induction with different concentrations of D-xylan. Triplicate cells cultures supplemented with D-xylan were collected at 0 h, 2 h, 4.5 h, 10.5 h and 20 h, chilled on ice, and subjected to fluorescence measurement.

\section{Results and discussion}

\subsection{Expression of FbFP in C. cellulolyticum $H 10$}

A reliable fluorescent reporter system was the premise for effective screening of promoter activities. The C. cellulolyticum-E. coli shuttle vector pMTC6 harbors the $f b f p$ gene from $P$. putida driven by the pthl promoter (thiolase gene promoter from $C$. acetobutylicum) (Cui et al., 2012) (Fig. 1A). To confirm the expression of $f b f p$, green fluorescence was examined by the BlueStar flashlight package (NightSea, UK) (Li and Wolf, 2011). As expected, fluorescence was only detected in the $C$. cellulolyticum harboring pMTC6, but not in the wild-type strain (Fig. 1B). Meanwhile, the protein product of $f b f p$ (FbFP, $\sim 16 \mathrm{kDa}$ ) was only obtained in pMTC6-harbored cells on the SDS-PAGE gel, indicating successful expression of $f b f p$ (447 bp) (Cui et al., 2012) (Fig. 1C). In addition, results from LC-MS confirmed the correct sequence of FbFP (Drepper et al., 2007), demonstrating the expression and reliability of the green fluorescent reporter system (Fig. S1).

$\mathrm{FbFP}$, due to its oxygen independence, is suitable for evaluating promoter activity in the anaerobe $C$. cellulolyticum and probably other strict anaerobes. Compared to other reporter genes that are widely used such as AP (Shiraiwa et al., 2007), LacZ (Feustel et al., 2004; Thormann et al., 2002; Tummala et al., 1999), CAT (Nariya et al., 2011), GusA (Banerjee et al., 2014; Girbal et al., 2003; Hartman et al., 2011) and GFP (Shiraiwa et al., 2007; Yarbrough et al., 2001; Zhao et al., 2005), FbFP has many advantages. Firstly, due to the spontaneous fluorophore, FbFP can be directly visualized and easily measured in situ, while other enzymatic reaction based reporters (ERBRs) typically function in a more complicated manner. For instance, GusA activity measurement requires cellular extract preparation, substrate degradation and reaction quantification (Dong et al., 2012). Secondly, employing FbFP as the reporter avoids the interference of measurement by endogenous enzyme activity. On the other hand, there are certain limitations for FbFP. For example, although the oligomeric state of FbFP is found insensitive to ionic strength (Mukherjee et al., 2013), fluorescence of FbFP becomes much lower when E. coli cells were cultivated in LB medium with lower than $0.08 \mathrm{M} \mathrm{NaCl}$ (unpublished data). Such underestimation of fluorescence intensity resulted from low $\mathrm{NaCl}$ concentration can be avoided by washing via PBS buffer for each sample before fluorescence measurement.

\subsection{Fluorescence stability of FbFP}

In order to compare activities of promoters, fluorescence intensities of $C$. cellulolyticum cells were monitored during the whole cultivation 

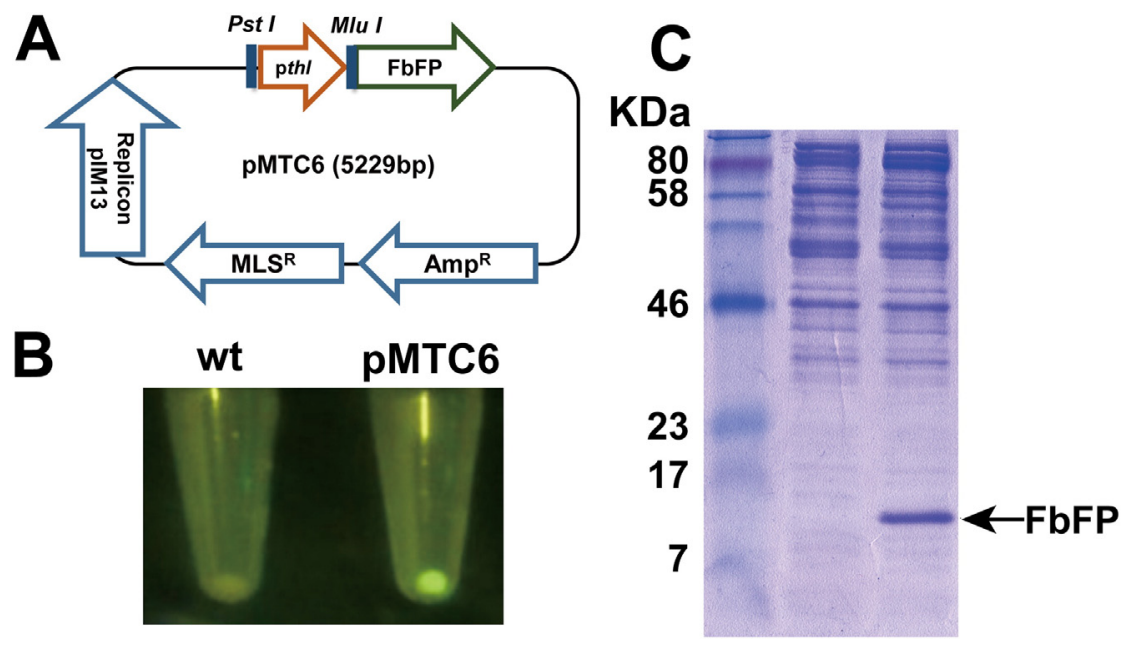

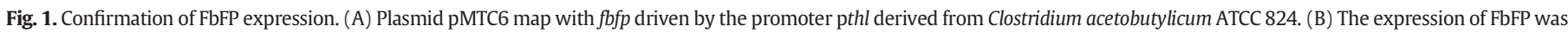
confirmed by fluorescence. (C) The expression of FbFP was confirmed by SDS-PAGE. (D) The amino acid sequence of the expressed FbFP was confirmed by LC-MS.

period of $48 \mathrm{~h}$, and normalized in two ways: cell optical density at $600 \mathrm{~nm}\left(\mathrm{~A}_{600}\right)$ and protein concentration (protein con.) (Fig. 2A). Meanwhile, the trend of fluorescence intensity without normalization was in accordance with the above two parameters in FbFP harboring cells (Fig. $2 \mathrm{~B})$, suggesting another way for tracking bacterial growth that is via fluorescence. Furthermore, fluorescence intensity of FbFP-harboring cells was found to be relatively stable between $20 \mathrm{~h}$ to $40 \mathrm{~h}$ for in situ measurement (normalized by cell density), while a longer period of fluorescence stability was apparent via the measurement of cellular extracts (normalized by protein con.) (Fig. 2C). In addition, for in situ fluorescence measurement, stability of fluorescence was further confirmed for an extended $20 \mathrm{~h}$ after cell sampling, in order to test the variation resulted from sampling. The result revealed no significant variance of fluorescence intensity from $0 \mathrm{~h}$ to $20 \mathrm{~h}$ (Fig. 2D; $p=0.37$ ( $p>0.05$ ); Kruskal-Wallis Rank Sum Test in R 3.03; $n=3$ ), indicating the reliability and stability of fluorescence.

The two ways for fluorescence intensity measurement, in situ (fluorescence normalized by $A_{600}$ ) or cell extracts (fluorescence normalized by total protein con.) were compared. The former was more advantageous in terms of convenience and simplicity, while the latter was
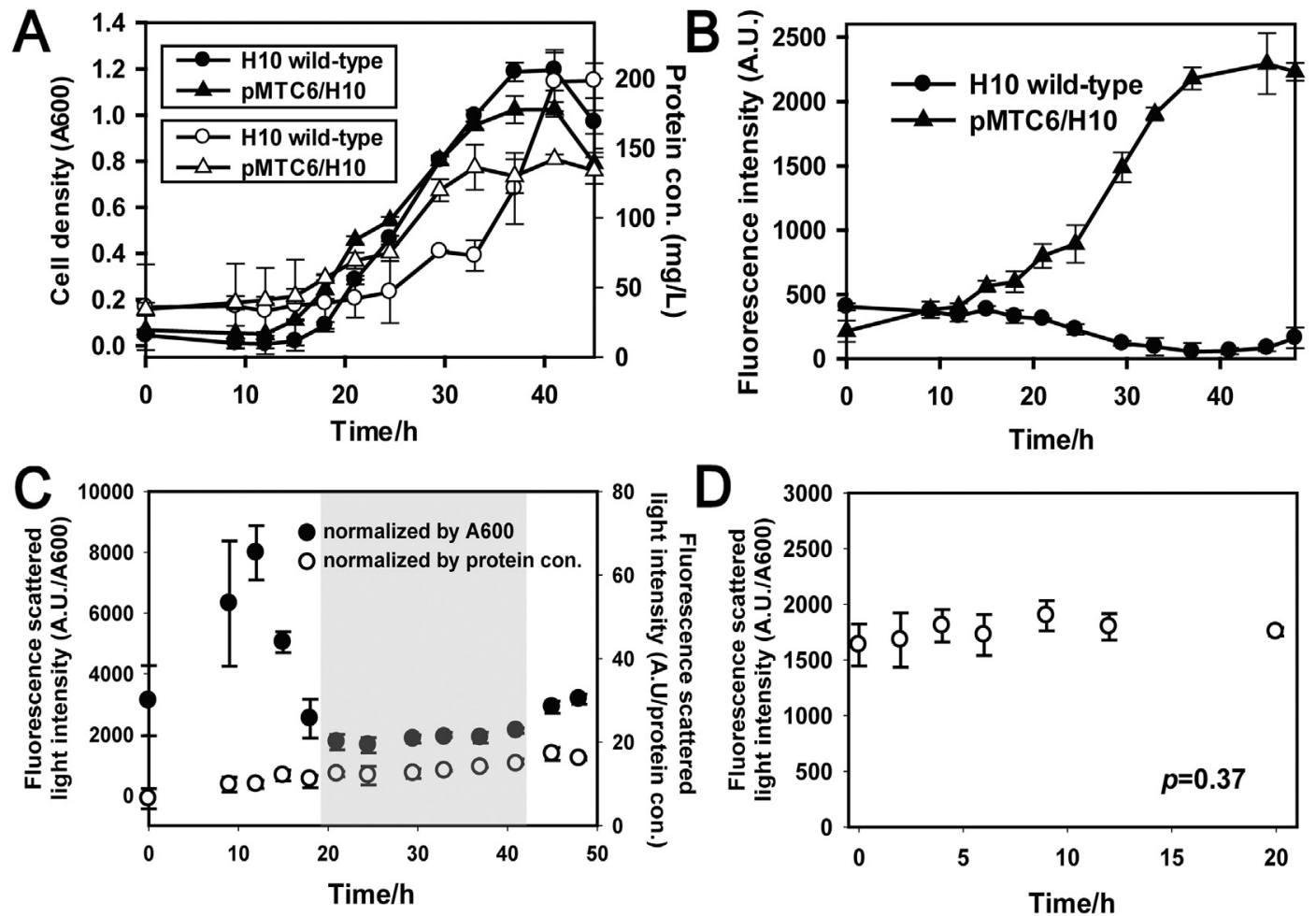

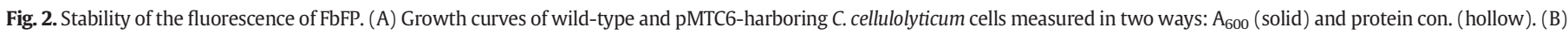

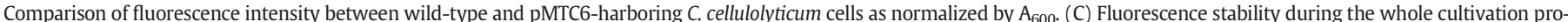

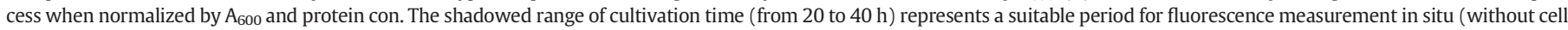

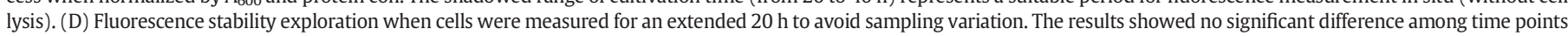
$(p=0.37$; tested by Kruskal-Wallis Wilcoxon Test in $\mathrm{R} 3.03)$. Values represent means $\pm \operatorname{SD}(\mathrm{n}=3)$. 
more stable for fluorescence intensity measurement. One possible reason for the instability of fluorescence normalized by $\mathrm{A}_{600}$ during the first $20 \mathrm{~h}$ is the variation of optical density for the small number of cells. Thus the fluorescence of cells might be measured in situ till midor late-exponential phase. Furthermore, the long period of stability of fluorescence intensity detected based on the above two methods might be due to the excellent intrinsic stability of FbFP, which is reported to be stable under various stresses (e.g., thermal stress that is up to $60{ }^{\circ} \mathrm{C} ; \mathrm{pH} 4-11$ (Mukherjee et al., 2013)). Moreover, fluorescence intensity measurement of FbFP was substrate-independent and could be carried out without strict condition, which was more advantageous than ERBRs, which were mostly substrate-dependent and had to be carried out under strict enzyme-reaction condition (e.g., temperature, mostly $37{ }^{\circ} \mathrm{C}$ (Nariya et al., 2011; Zhang et al., 2015) or $65{ }^{\circ} \mathrm{C}$ (Thormann et al., 2002)). In addition, since FbFP functions as a kind of "GFP", the method described in this study has great potential for high throughput screening of promoters in anaerobic organisms, such as the use of FACS for screening promoters of high activity in Corynebacterium glutamicum (Yim et al., 2013). Thus FbFP is promising as a reporter to monitor promoter activities.

\subsection{Analysis of promoter activity based on FbFP fluorescence intensity}

The stability of FbFP suggests its suitability as a reporter for screening promoters. From our previously published transcriptome datasets for $C$. cellulolyticum cells cultivated on various carbon sources (Xu et al., 2013), six promoters with relatively high transcriptional activities under any of the carbon sources were selected as candidates for promoter screening. Each of them was cloned into pMTC6, resulting in the replacement of pthl (Table 1). The transformants obtained were subjected to both fluorescence intensity and FbFP abundance quantification, with the latter quantified via SDS-PAGE (Fig. 3A). The observed fluorescence intensity and the FbFP abundance was closely correlated $\left(R^{2}=0.87\right.$; Fig. 3B), suggesting the reliability of FbFP as reporter.

However, a number of factors might impact the accuracy of promoter activity measurement. $i$ ) Plasmid copy number, the possibility of fluorescence variation due to plasmid copy number could be eliminated by employing of same situation for plasmid replication. Plasmids used in this study were derived from the same origin, with the same replicons and hosting bacteria (Abdou et al., 2008); ii) Cell status, fluorescence stability during the whole cultivation time, indicating no significant effects of cell division on fluorescence intensity (population level) and iii) Translation efficiency, consistency of SD sequence (and the sequence between SD sequence and the initiation codon (ATG)) among strains might contribute to the expression variation of FbFP.

\subsection{Characteristics of two types of promoters in C. cellulolyticum}

Based on the results of promoter activities, two native promoters (p3398 and p1133) with the highest and lowest fluorescence intensity on D-cellobiose were further studied under several carbon sources ( $3 \mathrm{~g} / \mathrm{L}$; D-cellobiose, D-xylose, L-arabinose, D-glucose and D-xylan) until late-exponential phase. The relative fluorescence intensity of P1133 (cells harboring promoter p1133 for FbFP) varied greatly (CV = $0.808 ; \mathrm{n}=3$ ) among different carbon sources, with the highest being under D-xylan and the lowest under D-cellobiose. However, that of P3398 (cells harboring promoter p3398 for FbFP) was found to be relatively stable among these substrates, exhibiting activity that is $\sim 1.5$-fold higher than pthl (a constitutive promoter with high activity derived from $C$. acetobutylicum and widely used in clostridia) ( $C V=0.098$; Fig. 4A; S3; $n=3$ ). These results suggested that p1133 might be a substrate-inducible promoter, while p3398 might be a highly efficient constitutive promoter in C. cellulolyticum.

Considering the significance of controllable gene regulation in genetic engineering and synthetic biology, efficiency and stringency of the inducible promoter 1133 were explored by a time-course induction experiment. As fluorescence intensity of FbFP as driven by p1133 was approximately 20 times higher when grown on D-xylan than that on D-cellobiose (Fig. 4A), we examined the fluorescence intensity from $0 \mathrm{~h}$ to $20 \mathrm{~h}$ after the addition of different amount of D-xylan. Under low concentrations of D-xylan induction, such as $0.001 \mathrm{~g} / \mathrm{L}$ or $0.01 \mathrm{~g} / \mathrm{L}$, the fluorescence intensity increased significantly ( 7 fold) after $4.5 \mathrm{~h}$, but decreased after $10 \mathrm{~h}$ due to the exhaustion of D-xylan. Furthermore, with the increase of inducer dosage, the fluorescence intensity increased over $20 \mathrm{~h}$ (Fig. 4B). These results indicated that D-xylan functioned as not just an inducer but also a carbon source. Thus, considering the cost and time, $\mathrm{a} \sim 10$-fold increase of fluorescence intensity with $0.001 \mathrm{~g} / \mathrm{L} \mathrm{D}$-xylan for $4.5 \mathrm{~h}$ ' induction is more suitable for applications.

Although the lactose-inducing system is widely used for gene expression regulation in bacteria, it is of low efficiency in Clostridium strains, which might be due to the inability to utilize lactose or galactose (Banerjee et al., 2014; Hartman et al., 2011). The D-xylan inducible system developed in this study is significant for a number of reasons. Firstly, the discovery of D-xylan inducible promoters has expanded the scope of inducible genetic elements in clostridia. Secondly, as D-xylan can be degraded by xylanase into xylose which showed much lower inducibility to p1133 than D-xylan, it should be possible to realize controlled induction. In contrast, induction by other monosaccharides such as Larabinose (Zhang et al., 2015) and D-xylose (Nariya et al., 2011) can be more difficult to control as they are directly consumed by the cell. Furthermore, since the promoter was endogenous, without introducing
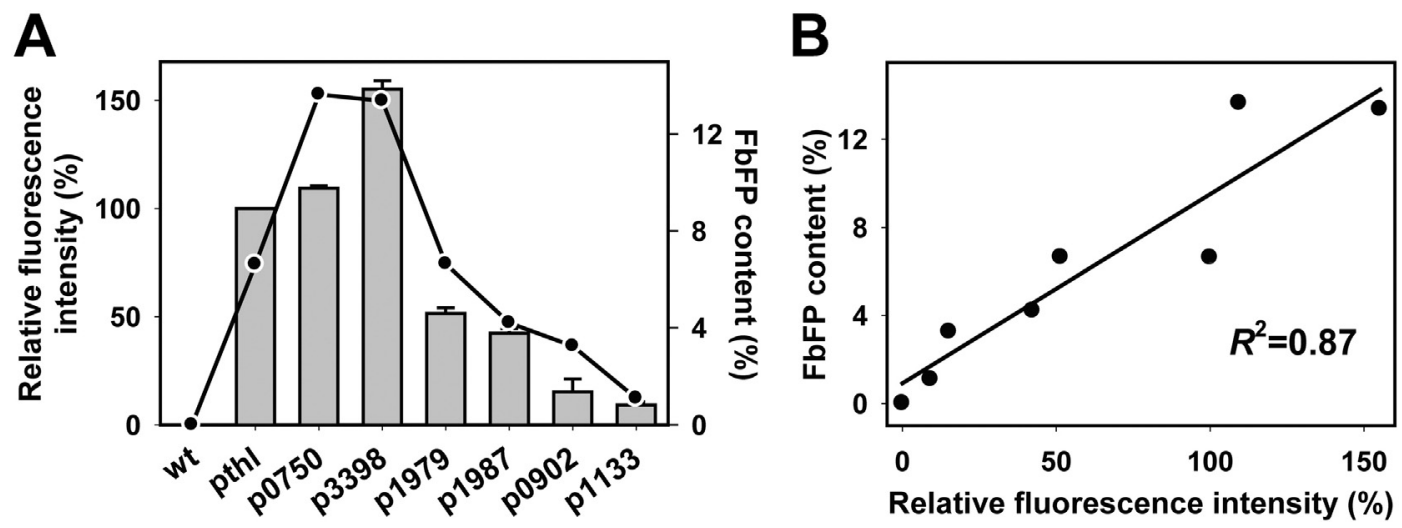

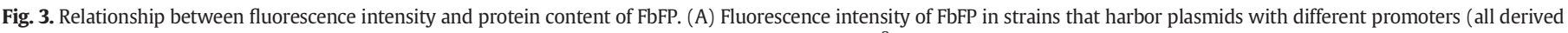

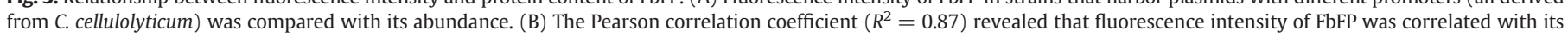
abundance. 

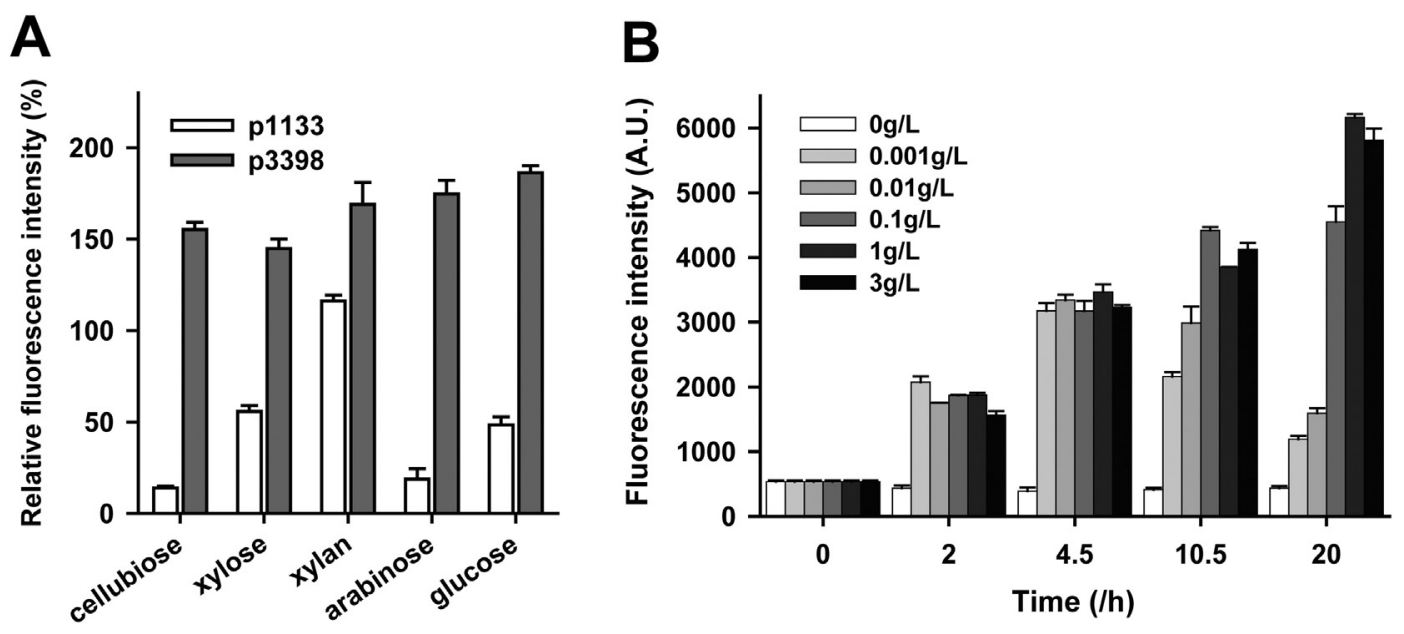

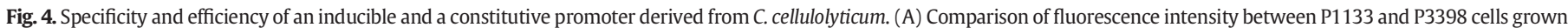

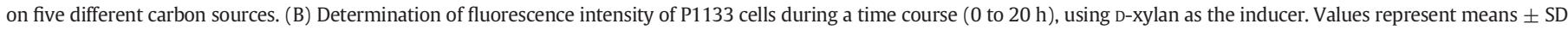
$(n=3)$.

the regulatory elements, there is no need to introduce new regulatory elements into C. cellulolyticum.

On the other hand, several limitations are apparent: i) stringency, it was suggested that for an optimal inducible expression system, promoter should be highly activated upon induction and efficiently repressed in the absence of inducer (Pyne et al., 2014). Stringency of p1133 to Dxylan was not perfect due to a certain level of background as observed on non-inducer (such as D-cellobiose). However, such a "leaky" feature can be exploited in the study of lethal or essential genes by replacing their original promoters with p1133. Moreover, by dissecting the mechanism of this inducible system, stringency of the promoter can be improved by genetic engineering 1133 sequence; and ii) the range of application, in this work, fluorescence intensity of P1133 cells was found to correlate with the dosage of D-xylan (i.e., $0.001 \mathrm{~g} / \mathrm{L}$ or $0.01 \mathrm{~g} / \mathrm{L}$ D-xylan) (Fig. 4B), indicating that D-xylan was utilized as a carbon source in C. cellulolyticum. Similar to other inducers widely used in clostridia (i.e., arabinose (Zhang et al., 2015)), application of this inducible system is likely restricted to those species capable of D-xylan utilization (e.g., the existence of ATP-binding cassette transporter for D-xylan or its degradation products (Xu et al., 2013)).

In contrast to inducible promoters, constitutive promoters also play key roles in metabolic engineering for its high activity under various conditions. p3398, a native constitutive promoter in C. cellulolyticum, exhibit higher promoter activity than pthl (a strong constitutive promoter in C. acetobutylicum (Tummala et al., 1999)) indicated by the fluorescence intensity, suggesting its potential use in other Clostridium strains due to its high efficiency.

\section{Concluding remarks}

In this work, we employed FbFP as a reporter and developed a new method for screening promoters in C. cellulolyticum. This method is advantageous due to its rapidity, simplicity and stability in fluorescence measurement. The method can be used not just for screening promoters but also for evaluation of other transcriptional regulatory components such as operator sequences or SD sequences in this and related cellulolytic bacteria. Moreover, two endogenous promoters with exceptional performance were identified and characterized, including a constitutive promoter p3398 and an inducible promoter p1133. They should serve as valuable tools for engineering of $C$. cellulolyticum or other clostridia for enhanced cellulolysis and biofuel production.

Supplementary data to this article can be found online at http://dx. doi.org/10.1016/j.mimet.2015.09.018.

\section{Acknowledgments}

We are grateful to Yun Wang for an English proofreading of this article. This work was supported by grant 2011CB707404 from the Ministry of Science and Technology of the People's Republic of China and 31200029 from the National Natural Science Foundation of China.

The authors declare no financial or commercial conflict of interest.

\section{References}

Abdou, L., Boileau, C., de Philip, P., Pages, S., Fierobe, H.P., Tardif, C., 2008. Transcriptional regulation of the Clostridium cellulolyticum cip-cel operon: a complex mechanism involving a catabolite-responsive element. J. Bacteriol. 190, 1499-1506.

Banerjee, A., Leang, C., Ueki, T., Nevin, K.P., Lovley, D.R., 2014. Lactose-inducible system for metabolic engineering of Clostridium ljungdahlii. Appl. Environ. Microbiol. 80, 2410-2416.

Blouzard, J.C., Coutinho, P.M., Fierobe, H.P., Henrissat, B., Lignon, S., Tardif, C., Pages, S., de Philip, P., 2010. Modulation of cellulosome composition in Clostridium cellulolyticum: adaptation to the polysaccharide environment revealed by proteomic and carbohydrate-active enzyme analyses. Proteomics 10, 541-554.

Campbell, R.E., 2004. Realization of beta-lactamase as a versatile fluorogenic reporter. Trends Biotechnol. 22, 208-211.

Cui, G.Z., Hong, W., Zhang, J., Li, W.L., Feng, Y.G., Liu, Y.J., Cui, Q., 2012. Targeted gene engineering in Clostridium cellulolyticum $\mathrm{H} 10$ without methylation. J. Microbiol. Meth. 89, 201-208.

Cui, G.Z., Zhang, J., Hong, W., Xu, C.G., Feng, Y.G., Cui, Q., Liu, Y.J., 2014. Improvement of ClosTron for successive gene disruption in Clostridium cellulolyticum using a pyrFbased screening system. Appl. Microbiol. Biotechnol. 98, 313-323.

Davis, S.J., Vierstra, R.D., 1998. Soluble, highly fluorescent variants of green fluorescent protein (GFP) for use in higher plants. Plant Mol. Biol. 36, 521-528.

Desvaux, M., 2005. Clostridium cellulolyticum: model organism of mesophilic cellulolytic clostridia. FEMS Microbiol. Rev. 29, 741-764.

Dong, H.J., Tao, W.W., Zhang, Y.P., Li, Y., 2012. Development of an anhydrotetracycline-inducible gene expression system for solvent-producing Clostridium acetobutylicum: a useful tool for strain engineering. Metab. Eng. 14, 59-67.

Dooley, C.T., Dore, T.M., Hanson, G.T., Jackson, W.C., Remington, S.J., Tsien, R.Y., 2004. Imaging dynamic redox changes in mammalian cells with green fluorescent protein indicators. J. Biol. Chem. 279, 22284-22293.

Drepper, T., Eggert, T., Circolone, F., Heck, A., Krauss, U., Guterl, J.K., Wendorff, M., Losi, A Gartner, W., Jaeger, K.E., 2007. Reporter proteins for in vivo fluorescence without oxygen. Nat. Biotechnol. 25, 443-445.

Ducrest, A.L., Amacker, M., Lingner, J., Nabholz, M., 2002. Detection of promoter activity by flow cytometric analysis of GFP reporter expression. Nucleic Acids Res. 30, e65.

Fendri, I., Abdou, L., Trotter, V., Dedieu, L., Maamar, H., Minton, N.P., Tardif, C., 2013. Regulation of cel genes of $C$. cellulolyticum: identification of GlyR2, a transcriptional regulator regulating cel5D gene expression. PLoS One 8. http://dx.doi.org/10.1371/ journal.pone.0044708.

Feustel, L., Nakotte, S., Durre, P., 2004. Characterization and development of two reporter gene systems for Clostridium acetobutylicum. Appl. Environ. Microbiol. 70, 798-803.

Girbal, L., Mortier-Barriere, I., Raynaud, F., Rouanet, C., Croux, C., Soucaille, P., 2003. Development of a sensitive gene expression reporter system and an inducible promoterrepressor system for Clostridium acetobutylicum. Appl. Environ. Microbiol. 69, 4985-4988. 
Guedon, E., Desvaux, M., Petitdemange, H., 2002. Improvement of cellulolytic properties of Clostridium cellulolyticum by metabolic engineering. Appl. Environ. Microbiol. 68, 53-58.

Hartman, A.H., Liu, H.L., Melville, S.B., 2011. Construction and characterization of a lactose-inducible promoter system for controlled gene expression in Clostridium perfringens. Appl. Environ. Microbiol. 77, 471-478.

Hemme, C.L., Mouttaki, H., Lee, Y.J., Zhang, G.X., Goodwin, L., Lucas, S., Copeland, A. Lapidus, A., del Rio, T.G., Tice, H., Saunders, E., Brettin, T., Detter, J.C., Han, C.S. Pitluck, S., Land, M.L., Hauser, L.J., Kyrpides, N., Mikhailova, N., He, Z.L., Wu, L.Y., Van Nostrand, J.D., Henrissat, B., He, Q., Lawson, P.A., Tanner, R.S., Lynd, L.R., Wiegel, J., Fields, M.W., Arkin, A.P., Schadt, C.W., Stevenson, B.S., McInerney, M.J., Yang, Y.F., Dong, H.L., Xing, D.F., Ren, N.Q., Wang, A.J., Huhnke, R.L., Mielenz, J.R., Ding, S.Y., Himmel, M.E., Taghavi, S., van der Lelie, D., Rubin, E.M., Zhou, J.Z., 2010. Sequencing of multiple clostridial genomes related to biomass conversion and biofuel production. J. Bacteriol. 192, 6494-6496.

Higashide, W., Li, Y., Yang, Y., Liao, J.C., 2011. Metabolic engineering of Clostridium cellulolyticum for production of isobutanol from cellulose. Appl. Environ. Microbiol. 77, 2727-2733.

Jiang, T.T., Xing, B.G., Rao, J.H., 2008. Recent developments of biological reporter technology for detecting gene expression. Biotechnol. Genet. Eng. 25, 41-75.

Laemmli, U.K., 1970. Cleavage of structural proteins during the assembly of the head of bacteriophage T4. Nature 227, 680-685.

Leveau, J.H.J., Lindow, S.E., 2001. Predictive and interpretive simulation of green fluorescent protein expression in reporter bacteria. J. Bacteriol. 183, 6752-6762.

Li, X., Wolf, M.E., 2011. Visualization of virus-infected brain regions using a GFP-illuminating flashlight enables accurate and rapid dissection for biochemical analysis. J. Neurosci. Methods 201, 177-179.

Li, Y.C., Tschaplinski, T.J., Engle, N.L., Hamilton, C.Y., Rodriguez, M., Liao, J.C., Schadt, C.W. Guss, A.M., Yang, Y.F., Graham, D.E., 2012. Combined inactivation of the Clostridium cellulolyticum lactate and malate dehydrogenase genes substantially increases ethanol yield from cellulose and switchgrass fermentations. Biotechnol. Biofuels 5 http://dx.doi.org/10.1186/1754-6834-5-2.

Lin, L., Song, H.H., Tu, Q.C., Qin, Y.J., Zhou, A.F., Liu, W.B., He, Z.L., Zhou, J.Z., Xu, J., 2011. The Thermoanaerobacter glycobiome reveals mechanisms of pentose and hexose co-utilization in bacteria. Plos Genet. 7.

Lobo, L.A., Smith, C.J., Rocha, E.R., 2011. Flavin mononucleotide (FMN)-based fluorescent protein (FbF) as reporter for gene expression in the anaerobe Bacteroides fragilis. FEMS Microbiol. Lett. 317, 67-74.

Loffler, F.E., Sanford, R.A., Tiedje, J.M., 1996. Initial characterization of a reductive dehalogenase from Desulfitobacterium chlororespirans Co23. Appl. Environ. Microbiol. $62,3809-3813$

Lynd, L.R., van Zyl, W.H., McBride, J.E., Laser, M., 2005. Consolidated bioprocessing of cellulosic biomass: an update. Curr. Opin. Biotechnol. 16, 577-583.

Madarro, A., Pena, J.L., Lequerica, J.L., Valles, S., Gay, R., Flors, A., 1991. Partial-purification and characterization of the cellulases from Clostridium cellulolyticum H10. J. Chem. Technol. Biotechnol. 52, 393-406

Mingardon, F., Chanal, A., Tardif, C., Fierobe, H.P., 2011. The issue of secretion in heterologous expression of Clostridium cellulolyticum cellulase-encoding genes in Clostridium acetobutylicum ATCC 824. Appl. Environ. Microbiol. 77, 2831-2838.

Mohand-Oussaid, O., Payot, S., Guedon, E., Gelhaye, E., Youyou, A., Petitdemange, H., 1999. The extracellular xylan degradative system in Clostridium cellulolyticum cultivated on xylan: evidence for cell-free cellulosome production. J. Bacteriol. 181, 4035-4040.

Mukherjee, A., Walker, J., Weyant, K.B., Schroeder, C.M., 2013. Characterization of flavinbased fluorescent proteins: an emerging class of fluorescent reporters. PLoS ONE 8.
Nariya, H., Miyata, S., Kuwahara, T., Okabe, A., 2011. Development and characterization of a xylose-inducible gene expression system for Clostridium perfringens. Appl. Environ. Microbiol. 77, 8439-8441.

Petitdemange, E., Caillet, F., Giallo, J., Gaudin, C., 1984. Clostridium cellulolyticum Sp-Nov, a cellulolytic, mesophilic species from decayed grass. Int. J. Syst. Bacteriol. 34, 155-159.

Phillips-Jones, M.K., 2000. Use of a lux reporter system for monitoring rapid changes in alpha-toxin gene expression in Clostridium perfringens during growth. FEMS Microbiol. Lett. 188, 29-33.

Pyne, M.E., Bruder, M., Moo-Young, M., Chung, D.A., Chou, C.P., 2014. Technical guide for genetic advancement of underdeveloped and intractable Clostridium. Biotechnol. Adv. 32, 623-641.

Saxena, S., Fierobe, H.P., Gaudin, C., Guerlesquin, F., Belaich, J.P., 1995. Biochemical properties of a beta-xylosidase from Clostridium cellulolyticum. Appl. Environ. Microbiol. 61, 3509-3512.

Schwarz, S., Kehrenberg, C., Doublet, B., Cloeckaert, A., 2004. Molecular basis of bacterial resistance to chloramphenicol and florfenicol. FEMS Microbiol. Rev. 28, 519-542.

Shao, L., Hu, S., Yang, Y., Gu, Y., Chen, J., Yang, Y., Jiang, W., Yang, S., 2007. Targeted gene disruption by use of a group II intron (targetron) vector in Clostridium acetobutylicum. Cell Res. 17, 963-965.

Shiraiwa, T., Kaneto, H., Miyatsuka, T., Kato, K., Yamamoto, K., Kawashima, A., Kajimoto, Y., Matsuoka, T.A., Matsuhisa, M., Yamasaki, Y., Fujitani, Y., 2007. Establishment of a noninvasive mouse reporter model for monitoring in vivo pdx-1 promoter activity. Biochem. Biophys. Res. Commun. 361, 739-744.

Tardif, C., Maamar, H., Balfin, M., Belaich, J.P., 2001. Electrotransformation studies in Clostridium cellulolyticum. J. Ind. Microbiol. Biotechnol. 27, 271-274.

Thormann, K., Feustel, L., Lorenz, K., Nakotte, S., Durre, P., 2002. Control of butanol formation in Clostridium acetobutylicum by transcriptional activation. J. Bacteriol. 184, 1966-1973.

Tummala, S.B., Welker, N.E. Papoutsakis, ET, 1999. Development and characterization of a gene expression reporter system for Clostridium acetobutylicum ATCC 824. Appl. Environ. Microbiol. 65, 3793-3799.

Wong, C., Sridhara, S., Bardwell, J.C.A., Jakob, U., 2000. Heating greatly speeds Coomassie blue staining and destaining. Biotechniques 28, 426-432.

Xu, C., Huang, R., Teng, L., Wang, D., Hemme, C.L., Borovok, I., He, Q., Lamed, R., Bayer, E.A., Zhou, J., Xu, J., 2013. Structure and regulation of the cellulose degradome in Clostridium cellulolyticum. Biotechnol. Biofuels 6, 73 .

Xu, T., Li, Y.C., Van Nostrand, J.D., He, Z.L., Zhou, J.Z., 2014. Cas9-based tools for targeted genome editing and transcriptional control. Appl. Environ. Microbiol. 80, 1544-1552.

Xu, C., Huang, R., Teng, L., Jing, X.Y., Hu, J.Q., Cui, G.Z., Wang, Y.L., Cui, O., Xu, J., 2015. Cellulosome stoichiometry in Clostridium cellulolyticum is regulated by selective RNA processing and stabilization. Nat. Commun. 6. http://dx.doi.org/10.1038/ ncomms7900.

Yarbrough, D., Wachter, R.M., Kallio, K., Matz, M.V., Remington, S.J., 2001. Refined crystal structure of DsRed, a red fluorescent protein from coral, at 2.0-angstrom resolution. Proc. Natl. Acad. Sci. U.S.A. 98, 462-467.

Yim, S.S., An, S.J., Kang, M., Lee, J., Jeong, K.J., 2013. Isolation of fully synthetic promoters for high-level gene expression in Corynebacterium glutamicum. Biotechnol. Bioeng. 110, 2959-2969.

Zhang, J., Liu, Y.J., Cui, G.Z., Cui, Q., 2015. A novel arabinose-inducible genetic operation system developed for Clostridium cellulolyticum. Biotechnol. Biofuels 8, 36.

Zhao, M., Yang, M., Li, X.M., Jiang, P., Baranov, E., Li, S.K., Xu, M.X., Penman, S., Hoffman, R.M., 2005. Tumor-targeting bacterial therapy with amino acid auxotrophs of GFP-expressing Salmonella typhimurium. Proc. Natl. Acad. Sci. U.S.A. 102, 755-760. 